\title{
KISTA EPIDERMOID TERINFLAMASI YANG MENYERUPAI GRANULOMA PIOGENIK PADA ANAK
}

\author{
Widyastuti, Yulia Farida Yahya \\ Departemen/BagianDermatologi dan Venereologi \\ FK UNSRI/Rumah Sakit Umum Pusat Dr.Moh. Hoesin Palembang

\begin{abstract}
ABSTRAK
Kista epidermoid merupakan salah satu tumor kista jinak yang dilapisi epitel skuamosa dan berisi keratin. Secara klinis memberi gambaran khas berupa nodus sewarna kulit atau kekuningan dan tidak nyeri, dengan pungtum sentral pada folikel pilosebasea. Kista epidermoid terinflamasi sering salah diagnosis sebagai granuloma piogenik. Dilaporkan satu kasus anak perempuan dengan kista epidermoid terinflamasi yang menyerupai granuloma piogenik.

Seorang anak perempuan berusia 11 tahun, dibawa berobat dengan keluhan benjolan merah di pipi kanan yang bertambah besar sejak 2 bulan lalu. Permukaan lesi licin dan tidak nyeri. Riwayat trauma tidak diketahui. Pada pemeriksaan di regio maksilaris dekstra ditemukan tumor eritematosa-livid, bulat, soliter, $1 \times 1 \times 0,5 \mathrm{~cm}$, dengan pungtum sentral. Dilakukan shave eksisi dilanjutkan bedah listrik dengan modalitas koagulasi. Hasil pemeriksaan histopatologik menunjukkan kista epidermoid dilapisi epitel skuamosa kompleks berkeratin dengan lumen berisi massa keratin.

Kista epidermoid terinflamasi jarang dijumpai. Gambaran histopatologis menunjukkan kista dilapisi epitel skuamosa berlapis dengan lapisan granular utuh berisi massa keratin. Kista epidermoid terinflamasi diduga akibat trauma yang memicu respons inflamasi dan jaringan granulasi sehingga terbentuk granuloma piogenik.

Granuloma piogenik dapat terjadi pada lesi kista epidermoid akibat trauma. Pada kasus dengan gambaran klinis menyerupai granuloma piogenik, pemeriksaan histopatologik diperlukan untuk menegakkan diagnosis pasti.
\end{abstract}

Kata kunci: Kista epidermoid dengan inflamasi, granuloma piogenik, gambaran klinis, histopatologis

\section{INFLAMED EPIDERMOID CYSTS PRESENTING AS PYOGENIC GRANULOMA ON CHILD}

\begin{abstract}
Epidermoid cyst is a benign cyst tumor of squamous epithelium and contain keratin. Clinically, the typical features is yellowish-colored skin nodule, painless, with central punctum in pilosebaceous follicle. Inflammed epidermoid cysts often misdiagnosis with pyogenic granuloma. A case of inflammed epidermoid cyst presenting as pyogenic granuloma on child is report.

An 11-year old girl, came with complaints red bumps on the right cheek grew since 2 months ago. Smooth surface and painless. A history of trauma was unknown. Physical examination on maxillaris dextra region was found an erythematous-livid tumor, round, solitary, $1 \times 1 \times 0,5 \mathrm{~cm}$, with central punctum. Treatment was shave excision followed by electrosurgery with coagulation modality Histopathological examination showed epidermoid cyst with keratinized squamous epithelium complex with its lumen contain a mass of keratin. Inflamed epidermoid cysts are rare. Histopathological features show cysts lined by stratified squamous lining with an intact granular layer. Inflamed epidermoid cyst may be due to trauma that triggers the inflammation and granulation tissue to form a pyogenic granuloma.

Pyogenic granuloma lesions may appear on epidermoid cyst after trauma. In cases with a clinical features resembling pyogenic granuloma, histopathological examination is needed to confirm the diagnosis.
\end{abstract}

Key word: Inflamed epidermoid cyst,pyogenic granuloma, clinical features, histopathology

Korespondensi:

Jl. Dr. Moh. Ali, Komplek RSUP MH,

Palembang 30126

Telp\&fax : 0711-314172 


\section{PENDAHULUAN}

Kista epidermoid merupakan kista berisi keratin yang dilapisi epitel, berasal dari epitel germinal epidermal dan dapat ditemukan di seluruh tubuh pada area tempat elemen embrionik menyatu bersama.1 Kista sering ditemukan pada usia dewasa dan lebih sering ditemukan pada lelaki dibandingkan dengan perempuan, rasio 3:1. Kista epidermoid berupa massa berbentuk kubah, lambat berkembang, dan asimptomatik. Kista dapat ruptur spontan atau akibat trauma, melepaskan materi keratin yang memicu respons inflamasi ataupun jaringan granulasi yang menyebabkan timbulnya granuloma piogenik. Granuloma piogenik merupakan lesi yang timbul sebagai respons terhadap trauma. Lesi umumnya tunggal, dapat timbul di seluruh tubuh, namun paling sering dan wajah dan tangan, khususnya jari. ${ }^{1}$

Kasus ini dilaporkan karena kista epidermoid terinflamasi yang menyerupai granuloma piogenik pada anak merupakan kasus unik dan jarang dijumpai. Pemeriksaan

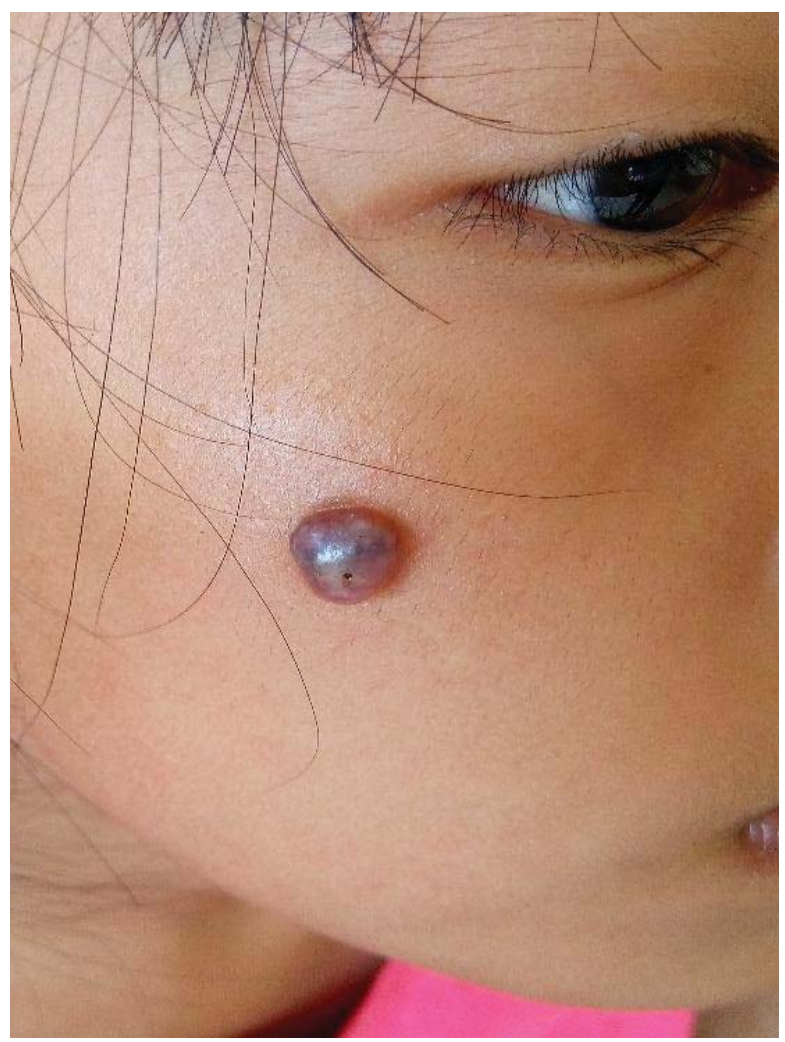

Gambar 1. Tampak nodus eritematosa, soliter dengan pungtum sentral di pipi kanan

Jaringan dilakukan pemeriksaan histopatologis, didapatkan hasil kista epidermoid dilapisi epitel skuamosa kompleks berkeratin dengan lumen berisi massa keratin histopatologis diperlukan untuk menegakkan diagnosis pasti.

\section{KASUS}

Seorang anak perempuan, berusia 11 tahun, sekitar 2 bulan lalu timbul papul eritematosa, soliter, milier di region maksilaris dekstra yang bertambah besar hingga menjadi nodus eritem ukuran lentikuler. Nodus tidak nyeri dan tidak mudah berdarah. Kulit di sekitar nodus normal. Pasien sering menggaruk lesi. Pasien tidak berobat.

Pada pemeriksaan fisik di regio maksilaris dekstra ditemukan nodus eritematosa-livid, soliter, $1 \times 1 \times 0,5 \mathrm{~cm}$, permukaan licin dengan punctum sentral, berbatas tegas, konsistensi lunak.(Gambar 1). Tidak ditemukan nyeri tekan. Gambaran dermoskopik dijumpai pungtum sentral (Gambar 2). Pasien didiagnosis sebagai granuloma piogenik, dilakukan tindakan eksisi shave dilanjutkan bedah listrik dengan modalitas koagulasi.

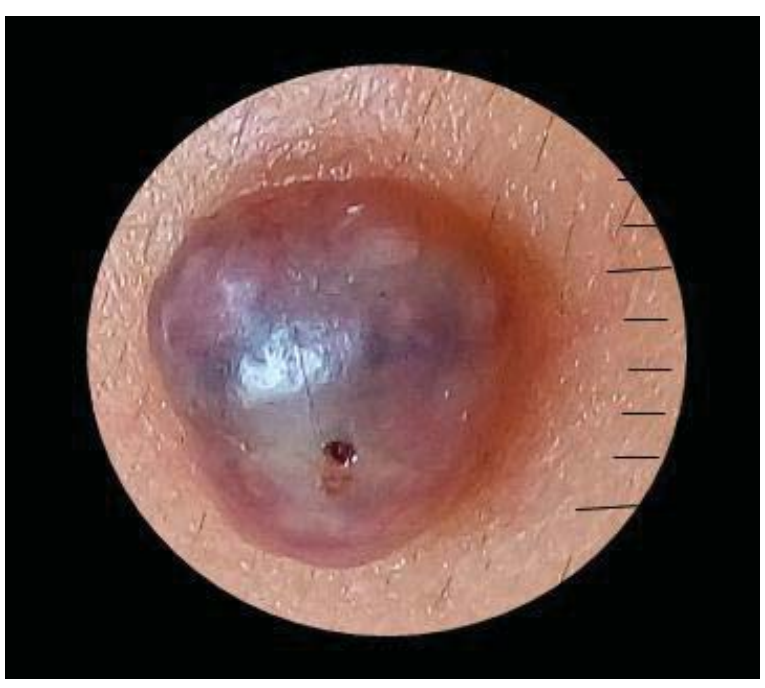

Gambar 2. Gambaran dermoskopik, tampak pungtum sentral.

(Gambar 3). Pada pengamatan 6 bulan tidak didapatkan rekurensi. 


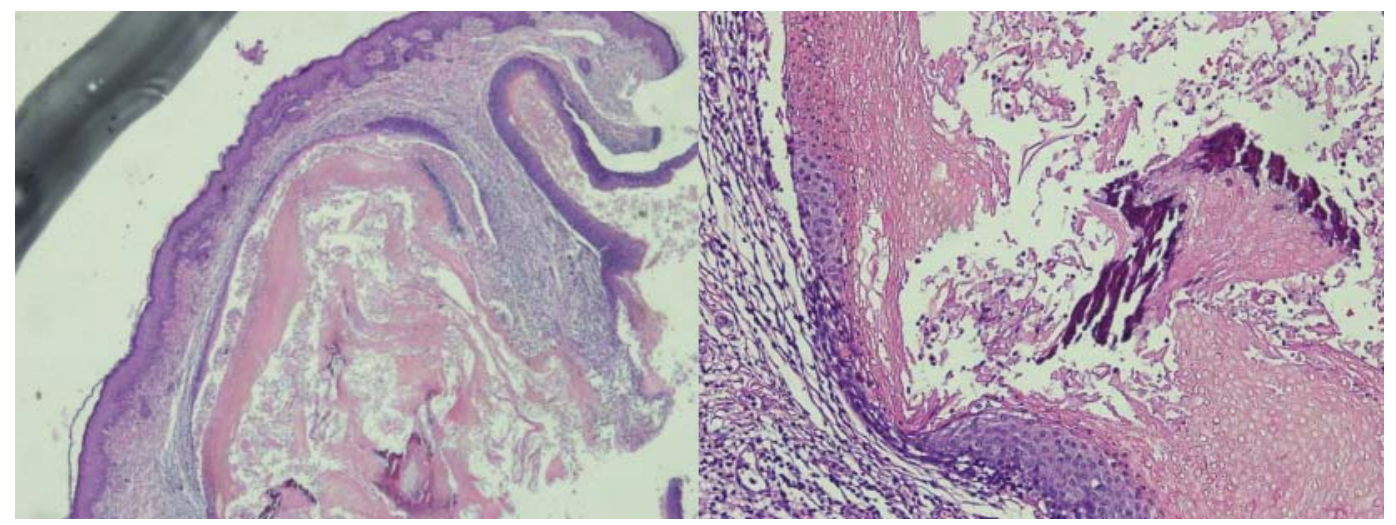

Gambar 3. Gambaran histopatologis, dalam dermis dijumpai kista dilapisi epitel skuamos kompleks berkeratin, lumen berisi massa keratin, dinding kista berupa jaringan ikat fibrokolagen di antaranya dijumpai pembuluh darah berisi sel darah merah

\section{DISKUSI}

Kista epidermoid merupakan tumor jinak kulit yang umumnya ditemukan pada usia dewasa muda dekade kedua dan ketiga kehidupan. Kista lebih sering ditemukan pada lelaki dibandingkan dengan perempuan. ${ }^{1} \mathrm{Na}-$ mun, pada kasus ini kista epidermoid ditemukan pada anak perempuan berusia 11 tahun.

Gambaran klinis kista epidermoid berupa nodus dermal atau subkutan sewarna kulit, putih atau kekuningan, dapat digerakkan, terdapat pungtum sentral. Pada palpasi teraba fluktuasi atau padat. Kista epidermoid berkembang lambat dan asimptomatik., ${ }^{2,3}$ Kista timbul khususnya pada area berambut. ${ }^{3}$ Kista dapat ruptur spontan atau akibat trauma sehingga menyebabkan masuknya materi keratin ke dalam dermis. Kondisi tersebut dapat memicu respons inflamasi dan jaringan granulasi sehingga terbentuk granuloma piogenikum. ${ }^{1,2}$ Granuloma piogenikum merupakan tumor vaskular yang timbul sebagai respons terhadap trauma. Gambaran klinis berupa papul atau nodus eritematosa, soliter sering disertai skuama kolaret dengan pertumbuhan yang cepat. Lesi dapat dapat timbul di seluruh tubuh, namun paling sering pada wajah dan tangan, khususnya jari. ${ }^{1}$ Granuloma piogenikum sering ditemukan pada bayi dan anak. ${ }^{4}$ Pada kasus ini dijumpai nodus eritematosa, soliter di pipi sehingga pasien didiagnosis sebagai granuloma piogenik. Namun, gambaran dermoskopis dijumpai pungtum sentral yang mirip dengan gambaran kista epidermoid. Pasien dilakukan tindakan eksisi shave dilanjutkan dengan bedah listrik dengan modalitas kaogulasi. Pada jaringan dilakukan pemeriksaan histopatologis dan didapatkan kesan kista epidermoid. Hasil pemeriksaan histopatologis tersebut tidak sesuai dengan gambaran klinis kasus yang lebih mengarah pada granuloma piogenik.

Kista epidermoid memiliki gambaran histopatologis khas berupa kista yang dilapisi sel skuamosa dengan lapisan granular utuh, sedangkan pada granuloma piogenik ditemukan proliferasi pembuluh darah kapiler dalam beberapa lobus. Lobus lebih dalam tampak padat namun semakin ke permukaan kepadatan berkurang dan lobus semakin besar. Lobus dipisahkan oleh jaringan ikat fibrosa. ${ }^{5}$ Pada kasus ini hasil pemeriksaan histopatologis menunjukkan dalam dermis dijumpai kista dilapisi epitel skuamosa kompleks berkeratin, lumen berisi massa keratin, dinding kista berupa jaringan ikat fibrokolagen yang di antaranya dijumpai pembuluh darah berisi sel darah merah. Hasil pemeriksaan tersebut menunjukkan materi kista dalam dermis yang memicu reaksi inflamasi, ditandai adanya pembuluh darah serta sel darah merah. Dugaan diagnosis kista epidermoid mengalami inflamasi akibat trauma sehingga memicu timbulnya granuloma piogenik di dalam kista. Hal tersebut sesuai dengan laporan kasus terdahulu oleh Hunt (1989) yang melaporkan dua granuloma piogenik berada pada dinding dalam kista epidermoid. Hunt menduga granuloma piogenik terbentuk melalui dua hipotesis. Pertama, trauma atau manipulasi kista epidermoid menyebabkan kista ruptur, sehingga materi keratin masuk ke jaringan di bawahnya dan memicu respons inflamasi dan jaringan granulasi sehingga timbul granuloma piogenik. Kedua, mungkin melibatkan adanya jejas penetrasi tunggal pada kulit. Granuloma piogenikum mungkin berkembang ketika kista epidermoid terbentuk di sekitarnya. Inklusi epitel akibat trauma diduga menyebabkan terbentuknya kista epidermoid. Pertumbuhan granuloma piogenik yang cepat tidak konsisten dengan pertumbuhan kista epidermoid yang lambat, oleh karena itu granuloma piogenik dan kista epidermoid tidak mungkin timbul bersamaan. ${ }^{4}$ Berdasarkan gambaran klinis, dermoskopik serta histopatologik, kami menduga granuloma piogenik timbul dalam lesi kista epidermoid akibat trauma yang memicu respons inflamasi.

Pada kasus granuloma piogenikum ditemukan dengan gambaran klinis tidak spesifik, oleh karena itu dianjurkan pemeriksaan histopatologik untuk memastikan diagnosis kista epidermoid terinflamasi. 


\section{DAFTAR PUSTAKA}

1. Rastogi V, Puri N, Kaur G, Yadav L, Sharma R. Unusual cases of epidermoid cyst: case series. Int J Sci Study. 2013; 1: 72-6.

2. Thomas VD, Snavely NR, Lee KK, Swanson NA. Benign epithelial tumors, hamartomas, and hyperplasias. Dalam: Wolff K, Goldsmith LA, Katz SI, Gilchrest BA, Paller AS, Lefel DJ, penyunting. Fitzpatrick's Dermatology in General Medicine. Edisi ke-8. New York: McGraw Hill; 2012. h.1332-4.

3. Leung AK, Barankin B. Epidermoid cyst. Int J Clin Med Imaging. 2014;1(11): 1. http://dx.doi.org/10.4172/23760249.1000269.

4. Hunt SJ. Two pyogenic granulomas arising in an epidermoid cyst. Am J Dermatopathol. 1989; 4(11):360-3.

5. Weedon D. Tumors of the epidermis. Skin Pathology. Edisi ke-3. British: Elsevier; 2010. h.906-7. 